\title{
Pertahanan Jepang Pada Era Pasca Perang Dingin, Antara Nasionalisme Dan Konservatisme
}

\author{
Ani Khoirunnisa \\ Universitas 17 Agustus 1945 Jakarta \\ Ani_Khairunnisa@yahoo.com
}

\begin{abstract}
Defence and security are an important part of national policy. Japan that has been rise from its failure in the World War II and make various adjustments to the international security order. Despite reaping the pros and cons in international relations and get criticism will rise militarism of Japan. Japan has proven through increase the development of the domestic economy and continues to improve its positive image in foreign relations including defence and security policy. This papers will describe the condition.
\end{abstract}

Key Words : Security, National Policy, Defence

\section{PENDAHULUAN}

Ada dua kondisi yang menyertai perubahan, kondisi yang lebih baik yang memajukan suatu pemerintahan dan kondisi yang negatif yang menuju suatu kemunduran. Kondisi pertamalah yang cocok untuk gambaran sebuah Negara Jepang, sebuah Negara yang hancur porak-poranda akibat Bom Hiroshima dan Nagasaki, kini bangkit menjadi sebuah Negara yang mempunyai kekuatan ekonomi yang mampu mengimbangi Eropa dan Amerika Serikat. Pertumbuhan ekonomi dan pengembangan teknologi Jepang telah berkembang pada pengembangan kemampuan militer yang berarti bahwa sejak Perang 
Dunia II Jepang telah mampu mengembangkan kemampuannya menjadi kekuatan dibidang militer.

Terdapatnya payung perlindungan keamanan Amerika Serikat terhadap Jepang, membuat Jepang 100\% membangun ekonominya. Jepang juga dilindungi oleh Amerika Serikat untuk memasarkan komoditi-komoditi ekonominya dalam perdagangan Internasional yang memang dikuasai amerika serikat, sehingga membuat perekonomian Jepang terus melesat dengan cepat.

Adanya payung politik keamanan dari Amerika Serikat kemajuan ekonomi yang didapatnya dari pasar internasional membuat Jepang semakin lama semakin makmur. Selanjutnya masyarakat Jepang terbiasa mempertahankan nilai-nilai kemapanan, baik dalam bidang sosial, ekonomi, politik dan terutama dalam bidang pertahanan dan keamanan. Kecenderungan tersebut menjadi salah satu "determinan" mengapa Jepang dilematis untuk mengubah kebijakan pertahanan keamanannya meskipun telah terjadi perubahan - perubahan penting baik dalam lingkungan internasional.

Bebasnya tatanan keamanan internasional pasca perang dingin menuntut Jepang untuk meninjau kembali sistim pertahanan keamanan. Tuntutan tersebut antara lain datang dari:

1. Sebagian besar masyarakat Jepang yang dimanifestasikan dalam lembaga-lembaga politik dan elit-elitnya

2. Faktor keamanan regional dan tekanan Amerika Serikat agar Jepang turut menjaga dan membiayai keamanan internasional 
3. Kekhawatiran negara lain akan bangkitnya kembali militerisme Jepang.

\section{PEMBAHASAN}

\section{a. Pertumbuhan Ekonomi Jepang}

Jepang adalah satu-satunya negara yang pertumbuhan ekonominya paling cepat di dunia. Karena begitu cepat pertumbuhannya banyak kalangan yang mengatakan Jepang adalah negara ajaib (miracle economy). Keajaiban ini dapat dilihat dari beberapa indikator ekonomi yang terus meningkat seperti tingkat produksi dan lainnya.

Menurut Ezra F. Vogel (1982;25-26) menjelang tahun 1952, yakni ketika pendudukan sekutu berakhir, Jepang kembali mencapai tingkat produksi sebelum perang. Hal ini dikuatkan oleh Yoshihara Kunio; "Pada akhir masa pendudukan, produksi pertanian, produksi pendapatan nasional. pendapatan perkapita, komsumsi perkapita, produktifitas tenaga kerja, upah nyata dan sebagian besar indikator lainnya mengenai pembangunan ekonomi telah kembali pada tingkat tahun 19341936” (Kunio Y, $1992: 20)$.

Suatu hal yang spektakuler dan fantastis, Jepang dalam sekian tahun saja dapat mencapai pertumbuhan seperti ketika negara ini siap-siap masuk kancah Perang Dunia II. Sedangkan dalam hal pendapatan nasional kotor (GNP/Gross National Product) pada awal-awal tahun tersebut, Jepang hanya mencapai sekitar sepertiga GNP Perancis atau Inggris Raya. Namun menjelang akhir tahun 1970-an GNP Jepang sudah sebesar GNP Inggris Raya dan Perancis bahkan menjadikan lebih besar 
dari separuh GNP Amerika Serikat serta menyamai GNP Jerman Barat pada tahun 1968 (Vogel, E. F, $1982: 26$ dan Nakamura T, $1985: 75$ ).

Pertumbuhan GNP yang cepat ini menurut Takafusa Nakamura (1985:75) terjadi pada kurun waktu 1952 hingga 1973, dimana GNP Jepang tumbuh rata-rata 10\% pertahun. Dengan mengandalkan ekspor dalam perdagangan dunia yang meningkat tiga kali lipat dalam masa 1955-1977 (rata-rata pertumbuhan 7,6\% pertahun) dan juga faktor domestik seperti kenaikan $22 \%$ dalam investasi pabrik dan peralatan dari tahun 1951 sampai 1973 yang merupakan tenaga pendorong di belakang kebutuhan domestik yang pada gilirannya mendorong pertumbuhan yang pesat.

Pesatnya perdagangan dunia antara tahun 1955 hingga tahun 1970 tidak dapat dilepas dari tatanan ekonomi politik internasional yang dibentuk pada pertemuan Bretton Woods tahun 1944 yang menghasilkan International Monetry Fund (IMF) dan General Agreement Tariff and Trade (GATT) serta World Bank (WB/IBRD). Ketiga badan ini sebagaimana sejarahnya di bidangi oleh Amerika Serikat yang sangat bersemangat untuk mewujudkan perdagangan yang liberal di seluruh dunia. Pemimpin-pemimpin Amerika Serikat pada waktu itu berketetapan hati bahwa untuk mencapai perdamaian dunia dan demi kemakmuran global harus dilakukan upaya untuk mendorong pertukaran barang dan kapital secara internasional yang relatif bebas.

Untuk membentuk cita-cita dibentuklah GATT, yang merupakan kodifikasi aturan aturan yang secara legal meningkat bagi pelaksanaan perdagangan di antara Negara-negara anggotanya. Lembaga yang berkantor di Genewa, Swiss ini juga 
menyediakan infrastruktur dan merupakan tempat bagi sebuah perundingan multilateral mengenai pengurangan tarif sejak Perang Dunia II. Tujuan umumnya adalah memaksimalkan pertumbuhan perdagangan dunia dan ekonomi global melalui pengurangan hambatan tarif atas dasar non diskriminasi.

GATT ditemani oleh IMF yang terbentuk pada tahun 1944 dengan fungsi yang komplementer dengan fungsi GATT, yaitu meningkatkan stabilitas dan Liberalisasi transaksi moneter Internasional. Tujuan GATT tidak mungkin tercapai tanpa penyediaan devisa yang cukup secara global maupun kemungkinan terjadinya mobilitas kapital untuk membiayai perdagangan internasional. Melalui IMF, Negara-negara didorong untuk menerapkan kebijakan moneter yang bertanggung jawab. Kedua lembaga ini bersama-sama dengan Bank Dunia menjadi fondasi bagi upaya-upaya multilateral untuk menjaga konsekuensi politik dan ekonomi dari nasionalisme ekonomi yang mendorong timbulnya Perang Dunia ke II.

Bagi Negara Jepang, yang sebagian besar tergantung perdagangan luar negeri, ditambah hubungannya yang sangat erat dengan Amerika Serikat, sistim ekonomi baru demikian sangat berharga. Tidak hanya memungkinkan Jepang dapat meningkatkan volume perdagangan luar negerinya dan untuk memperoleh lebih besar keuntungan dari perdagangan ini, tetapi juga telah memberikan sumbangan untuk meningkatkan efisiensi dengan mendukung perubahan-perubahan Jepang pada persaingan internasional dan memperbesar pangsa pasarnya. Diakui bahwa perubahan-perubahan yang berorientasi ekspor harus berusaha keras terus menerus lebih efisiensi yang lebih besar karena persaingan dalam pasar ekspor. Selain itu 
yang cukup menarik adalah perusahaan yang memiliki sebagian besar memiliki pasar di dalam negeripun harus menghadapi persaingan luar negeri karena kebijakan impor yang bebas dan tariff yang telah dikurangi. Dengan sistim perekonomian baru, pada awal tahun 1970an perekonomian Jepang menjadi erat terpadu dengan perekonomian internasional. (Kunio Y, 1992 : 20).

Terpadunya perekonomian Jepang dalam gelanggang internasional membuat pertumbuhan ekonomi negeri ini semakin berkembang dengan pesat. Pertumbuhan ini hampir tidak punya rintangan, kecuali ketika Negara-negara Arab/Negara-negara pengekspor minyak melakukan embargo pada tahun 1973, yang menuntut agar Negara-negara Barat seperti Amerika Serikat dan beberapa Negara di Eropa Barat menghentikan dukungannya terhadap Israel.

Pada waktu embargo berlangsung perekonomian Jepang memang mengalami pukulan berat. Berapa besarnya pukulan itu sampai membuat pertumbuhan ekonominya menjadi minus 1,3 dalam tahun 1974(Kunio Y, 1992:23). Akan tetapi sebagaimana dikatakan Yoshiro Kunio(1992 23) pengaruh embargo ini hanya bersifat sementara. Pasca embargo, pertumbuhan ekonomi Jepang malah melesat semakin cepat ketimbang era-era sebelumnya.

Betapa cepatnya pertumbuhan ekonomi Jepang ini tidak saja Jepang menjadi raksasa ekonomi dunia, namun juga melahirkan dampak dampak bagi pertumbuhan ekonomi Negara lain. Dampak ini misalnya adalah betapa ekspor negara-negara lain tersebut merosot, bahkan terhenti karena telah dikuasai oleh komoditi komoditi Jepang yang ternyata lebih berkualitas dan lebih murah dalam hampir semua 
komoditi. Namun dampak yang paling menarik adalah dalam hubungan perdagangan antara Jepang dan Amerika Serikat. Dalam hubungan ini Jepang selalu mengalami surplus, sebaliknya Amerika Serikat mengalami defisit, yang berakibat hubungan kedua Negara mengalami krisis, Bagaimana krisis ini berlangsung tidak akan dibahas lebih lauh dalam tulisan ini, selain kasusnya masih terus berlangsung akan mungkin diuraikan lebih lanjut.

\section{b. Perubahan-Perubahan Global-Regional Pasca Perang Dingin}

Berakhirnya perang dingin yang di manifestasikan dengan ambruknya Uni Soviet pada tahun 1991 telah membawa perubahan- perubahan yang signifikan dalam tatanan internasional (Winarno B, 1993 : 27). Perubahan signifikan ini menyangkut empat hal yakni:

\section{Dari masalah politik kemasalah ekonomi}

Pada era perang dingin konsentrasi hubungan internasional terletak pada segi keamanan. Tuntutan perkembangan dunia yang pesat maupun membelokkan arah konsentrasi Amerika Serikat dan Uni Soviat dari militer/politik ke arah ekonomi, bahkan bagi Uni Soviet tatanan demikian sempat melahirkan ide Glasnost, Perestroika dan Democratizatizia untuk mengatasi krisis ekonomi negerinya. Akan tetapi dalam perkembangannya ide-ide tersebut malah menjadi pemicu meledaknya revolusi di negara-negara Eropa Timur dan Uni Soviet sendiri dan akhirnya menyebabkan terjadinya krisis yang meruntuhkan ideology komunis dan mengakhiri riwayat Uni Soviet sebagai Negara Adikuasa. Untuk 
mengejar ketinggalannya dan agar dapat turut ambil bagian secara berarti dalam perkembangan dunia yang akan datang serta mencegah semakin besar pengaruhnya maka tiada jalan lain kecuali mengurangi beban militer dan memulihkan kemampuan nasionalnya, bahkan ada kecenderungan melemparkan surplus peralatan perang ke negara lain khususnya ke negara dunia ketiga.

\section{Konflik global berkurang dan konflik regional meningkat}

Berkurangnya pengaruh dan peranan adikuasa dalam menjamin keamanan regional dan lokal, sebagai akibat beralihnya konsentrasi mereka ke bidang ekonomi dan adanya kecenderungan penjualan senjata sebagai upaya dalam upaya mengatasi beban anggaran militer serta larinya para ahli persenjataan ke negaranegara dunia ketiga seperti Timur Tengah dan Asia Selatan, maka akan terjadinya perlombaan kekuasaan persenjataan di tingkat regional meningkat. Situasi ini menandakan bahwa walaupun masalah ekonomi merupakan masalah utama dalam hubungan internasional, namun masalah politik tetap masih ada.

\section{Munculnya blok baru, yaitu Utara-Selatan menggantikan Timur-Barat}

Dalam rangka memenuhi kepentingan akibat tuntutan perkembangan dunia, Negara negara industri maju akan lebih condong bergabung atau bekerja sama dengan sesama negara maju, yang berarti GATT, Bank Dunia, IMF, kelompok G-7 yang merupakan sistim atau sumber ekonomi internasional yang dalam era perang dingin lebih banyak memberikan bantuan pembangunan pada Negara-negara Dunia Ketiga, kini bantuanya lebih banyak berpihak ke Blok Utara. Kondisi ini akan mengakibatkan kesenjangan ekonomi antara Blok Utara 
dan Selatan dan dapat mengarah kepada munculnya kembali dominasi yang kuat atas yang lemah. Masalah-masalah ekonomi akan menjadi masalah yang utama, yang akan menjadi dorongan utama bagi kegiatan bangsa-bangsa dalam hubungan internasional, namun sekaligus sebagai sebab utama yang akan menimbulkan konflik internasional.

\section{Era Konfrontasi berubah menjadi era kerjasama}

Hubungan internasional di bidang ekonomi memerlukan situasi dunia yang tenang, dapat memasuki perkembangan serta dapat ikut berperan di dunia internasional. maka harus memelihara dan menciptakan ikatan-ikatan persekutuan dan hubungan-hubungan persahabatan Yang berarti memerlukan dikembangkannya kerja sama melalui cara dialog, kompromi dan diplomasi.

Perubahan-perubahan demikian akan berimplikasi langsung dalam tatanan pertahanan Jepang. Sebab Amerika Serikat akan mengurangi biaya-biaya pengeluaran militer sebagaimana yang dilakukan pada era perang dingin. Amerika Serikat yang begitu besar mengeluarkan dana untuk membendung komunis, secara bertahap akan membangun perekonomiannya. Hal ini dapat dibuktikan ketika George Bush yang masih kuat dalam orientasi politik luar negeri dan pertahanan keamanan dalam orientasi kampanyenya yang dilakukan Bill Clinton yang lebih mengutamakan pembangunan ekonomi. Betapa besar minat rakyat Amerika Serikat dalam pembangunan ekonominya. Dibuktikan kembali dengan dipilihnya Bill Clinton untuk masa jabatan yang kedua. 
Sebagai konsekuensinya hal yang berbalik akan terjadi di Jepang, Jepang yang 100\% konsentrasi dalam pembangunan ekonomi di era perang dingin, dipaksa untuk meninjau kembali pertahanan keamanannya. Jepang tidak mungkin lagi mencicipi kembali kemewahan, paling perlindungan keamanan yang diberikan Amerika Serikat selama era sebelumnya. Dalam hubungan ini bagi Jepang ada dua macam tekanan yang berbeda pada perencanaan dan pertahanan regionalnya. Di satu pihak, pendapat yang membatasi tingkat pengeluaran biaya pertahanan yang tinggi (kalangan konservatif). Dipihak lain terdapat tekanan untuk pembangunan behan yang lebih besar dengan Amerika Serikat (kalangan moderat/nasionalist), Pandangan-pandangan yang jauh melewati konteks seperti ini banyak juga dikemukakan, seperti yang diprediksikan oleh Lee Kuan Yew sewaktu berkunjung di Eropa tahun 1990 (Winarno, 1993 : 6).

Menurut Lee Kuan Yew, Jepang akan cenderung menjadi suatu kekuatan militer yang independent pada pergantian abad XX. Kecenderungan seperti ini memang bukan hal yang mengada-ada. Jepang telah membuktikan kekuatan militernya pada Perang Dunia II Meskipun mereka kalah dalam perang tersebut, kekuatan militernya tidak dapat diabaikan. Alasan lain sebagimana diuraikan Ezra. F Vogel adalah kenyataan bahwa Jepang memiliki kecenderungan untuk selalu menjadi nomor satu dalam bidang apapun yang ingin ia capai.

Perubahan lain yang langsung berhubungan dengan Keamanan Jepang adalah faktor Cina : 
Selain pertumbuhan ekonomi dan dialog-dialog regional, bagian penting lainnya dari arsitektur keamanan Pasifik adalah kehadiran dan peran keamanan Cina. Pergeseran dalam pertimbangan kekuatan dalam era pasca Perang Dingin terjadi bersama tampilnya Cina sebagai kekuatan politik dan militer. Yang dikhawatirkan oleh Negara-negara di kawasan perang strategis Cina di masa depan. (Bondoro. B, 1998:318-319)

Dengan jumlah penduduknya yang mencapai 1,2 milyar orang, wilayah daratan yang luas dan mempunyai garis pantai sepanjang 18 ribu kilometer, Cina pada dasarnya negara terbesar di Asia, apalagi mempunyai pasukan lebih dari 3 juta personil dan angkatan laut yang sedang tumbuh pesat. Sebagai negara yang memiliki senjata nuklir dan pengekspor rudal-rudal balistik dan senjata-senjata konvensional, Cina merupakan kekuatan yang besar yang dapat mempengaruhi perimbangan keamanan regional (Winarno. B, 1993 : 10)

\section{c. Dilema Kebijakan Kekuatan Jepang Pasca Perang Dingin}

Permasalahan pertahanan-keamanan Jepang sesungguhnya telah mengemuka sejak Amerika Serikat melakukan pemerintahan pendudukan di Jepang dari tahun 1945 hingga tahun 1952. Puncak permasalahannya adalah bahwa Amerika Serikat memaksakan kehendaknya untuk melarang Jepang membangun angkatan perang. Jepang melalui pasal IX UUD-nya sama sekali tidak mengijinkan adanya angkatan perang. Protes demi protes tidak henti-hentinya akan pasal kontroversial ini. Begitu pula akan protes boleh tidaknya Jepang membangun angkatan perang tidak pernah berhenti dari perdekatan publik.

Pada era perang dingin, keinginan-keinginan untuk membangun angkatan perang selalu kandas, selain karena tekanan dari Amerika Serikat yang menggunakan Jepang 
sebagai aliansi atau benteng utama menghadapi Komunis di Asia Timur, adalah bahwa suasana tersebut sangat menguntungkan Jepang untuk merehabilitasi perekonomiannya yang hancur pada perang Dunia II. Jepang dengan payung nuklir Amerika Serikat tidak perlu lagi memikirkan atau membiayai masalah pertahanan keamanan, sebab semua sudah ditanggung Amerika Serikat. Tidak cukup sampai di situ, Jepang dilindungi untuk masuk dalam pasar global, semakin meningkatkan pertumbuham ekonominya.

Akan tetapi setelah perang dingin berakhir, keuntungan-keuntungan yang didapatkan Jepang pada era perang dingin tidak mungkin lagi dapat dipertahankan, mengingat perkembangan-perkembangan yang baru dalam hubungan politik internasional dan khususnya bangkitnya kembali "nasionalisme" bangsa Jepang (Maszudi.E, Suara Karya, 10 April 1996). Perkembangan-perkembangan hubungan politik internasional demikian paling tidak memunculkan dua hal. Pertama, berkurangnya pengaruh yang diemban Amerika Serikat selama Perang Dingin, sebab musuh utamanya telah tiada, Negara ini akan memperbaiki keadaan ekonominya yang sedang menurun. Kedua, permintaan negara-negara lain agar ikut secara langsung berpartisipasi memelihara keamanan dan perdamaian dunia.

Banyaknya negara-negara di dunia yang mengharapkan Jepang sudah layak untuk membangun kekuatan militer, untuk menciptakan sistim politik internasional yang menjelang abad XXI akan berwujud uniporal, dimana Jepang merupakan salah satu sudut kekuatan tersebut (Maszudi E, Suara Karya, 10 April 1996). 
Keinginan Negara-negara lain ini mempunyai dasar dan tujuan yang jelas. Jepang yang sudah begitu maju ekonominya sudah waktunya aktif memelihara keamanan dan perdamaian dunia dalam arti yang sebenarnya. Jepang tidak mungkin lagi untuk mempertahankan pola pertahanan "pasif" yang dikumandangkan pertama kali oleh Yoshida Shigeru sewaktu menjadi Perdana Menteri. Disisi lain, keinginan negara tersebut adalah upaya tahap demi tahap untuk mengurangi atau dominasi negara Amerika Serikat. Sesuai dengan perkembangan dunia yang semakin multipolar.

Perkembangan-perkembangan tersebut menjadi "kondisi dan motivasi" bangkitnya kembali "Nasionalisme" Jepang yang diredam selama perang dingin berlangsung. Pemimpin-pemimpin, tokoh-tokoh atau elit-alit yang sejak dulu telah memperjuangkan Jepang menjadi Negara yang mandiri dalam bidang pertahanan keamanan, disokong dengan munculnya "generasi baru pasca perang" ditambah lagi apa yang disebut "masyarakat pasca industri" yang cenderung lebih demokratis di banding generasi- generasi sebelumnya, yakni generasi-generasi konservatif. Kelompok-kelompok pembaharu yang demokrat ini dari waktu ke waktu terus bertambah jumlahnya. Sebagai salah satu manivestasinya dapat disebut Ichiro Ozawa, tokoh utama pemimpin dan LDP yang saat itu menjadi Ketua Partai Liberal.

Menurut Ozawa, Jepang pasca Perang Dingin sudah harus merombak total pola kebijakan pertahanan keamanannya, yakni mengikuti sejauh mana perkembangan ekonominya, Jepang yang berjaya akan tetap langgeng apabila mempunyai angkatan perang yang memadai sebagaimana pengalaman negara-negara lain baik yang ada 
saat ini maupun yang ada dalam sejarah sebelumnya. Begitupula akan kontribusinya dalam menjaga pertahanan keamanan internasional.

Pemikiran-pemikiran Ozawa demikian dikenal dengan istilah"bangsa yang normal (Ozawa 1,1995 : 75-81 dan Pamuji N M, Suara Pembaharuan, 24 April 1996), suatu "konsep" yang diakui oleh semua kalangan, namun mempunyai kendala besar dalam pelaksanaannya. Ozawa yang populer dengan sebutan "ekstrim kanan" mempunyai"simbol perlawanan yang mempunyai mitra dan pengikut yang terus bertambah. Mitra dan pengikut-pengikutnya adalah Toshiki Kainu, Kilchi Miyazawa, Hosokawa, Ryutaro Hashimoto, Yohei Kono dan lain-lain.

Sikap politik para tokoh yang umumnya dari LPD ini nyatanya belum memuaskan kolega mereka di LDP Banyak sosok LDP yang berperan lebih jauh, yakni menginginkan agar Jepang sungguh sungguh menjadi negara yang mandiri dalam bidang pertahanan. Akibat ketidak puasan ini beberapa pemimpin LDP keluar dari partai ini dan membuat partai baru yang dinamakan Sinshito, yang banyak diminati kelompok pembaharu dan khususnya generasi baru, sebab partai ini terang. terangan menolak dominasi Amerika Serikat dalam kemanan Jepang (Maszudi E, Suara Karya, 16 April 1996).

Sinshito dalam perjalanan selanjutnya menjadi partai yang super oposisi di parlemen (Diet). Mereka begitu gencar menyuarakan agar Jepang merubah format pada abad XXI. Tokoh tokoh Sinshito dan bebarapa rekannya dari LDP yang sehaluan, pada tahun 1993 terlibat perdebatan sengit di Parlemen, sebab mereka ingin agar konstitusi ciptaan Amerika Serikat segera diamandemen atau diganti sama 
sekali. Akan tetapi sebagaimana kenyataannya kelompok yang menolak, yakni kelompok yang konservatif masih tetap unggul.

Argumen yang dikemukakan kalangan konservatif, selain alasan-alasan klasik yang selalu diutarakan ketika Perang Dingin masih berlangsung. seperti masalah pasal IX UUD yang tidak mengijinkan Jepang membangun angkatan bersenjata, mengutamakan pembangunan ekonomi, dan lain-lain maksud terselubung, adalah apa yang mereka namakan satu adagium Keamanan internasional yang berlaku saat ini adalah keamanan Jepang juga. Oleh karena itu tatanan keamanan internasional merupakan sikap nasional Jepang ; "Kalangan konservatif di Jepang yang mempunyai pemikiran, bagi Jepang mengerem ekspansi kekuatan militer negaranya sendiri sudah menjadi tanggung jawab internasional dan oleh karena itu merupakan sikap nasional” (Mastudi E, suara Karya, 16 April 1996).

Suatu argumen yang dikemas dalam format baru, tetapi isinya tetap sebagaimana yang pernah dikemukakan pada era sebelumnya, yakni mereka tetap menginginkan sistim pertahanan-keamanan yang pasif, meski ada dalih pendukungnya. Dalih ini adalah keinginan Amerika Serikat untuk tetap berperan sebagai polisi internasional atau khususnya Asia Timur, Pasifik dan Regional.

Pasca Perang Dingin sebagaimana diuraikan di atas telah merubah arsitektur keamanan di Asia Timur. Cina yang tampil sebagai salah satu Negara medium nuklir, sebagaimana Inggris, Perancis yang dalam perang dingin menjadi sahabat akan berubah menjadi ancaman atau sebaliknya, hubungan erat antara Jepang dengan Amerika Serikat yang dahulu menguntungkan Cina di era Perang Dingin karena 
diarahkan untuk membendung Uni Soviet, berubah menjadi ancaman bagi Cina. Namun yang membuat situasi kawasan semakin tidak menentu munculnya Korea Utara sebagai kekuatan nuklir baru.

Korea Utara sejak pecahnya perang Korea pada awal 1950-an tidak pernah menghentikan pembangunan angkatan perangnya. Pembangunan Korea Utara ini menjadi argument bagi Jepang maupun Amerika Serikat membuat perjanjian baru dalam bidang pertahanan dan keamanan pada tanggal 23 September 1997 (Akhihiko, 2000 : 22). Suatu perjanjian yang secara subjektif tidak berbeda dengan perjanjianperjanjian sebelumnya. Bahkan menurut Partai oposisi, Ichiro ozawa, perjanjian baru ini mempunyai kontradisi dalam logika (Akhihiko T et-al: 2000-23).

Faktor terakhir yang membuat dilematis kebijakan pertahanan Jepang adalah kekhawatiran negara-negara lain. Khususnya negara sekitar Jepang akan bangkitnya kembali militerisme Jepang. Dalam menanggapi RUU PKO dan rencana perubahan konstitusi Jepang tahun 1992, Negara negara ini memberi tanggapan, seperti yang disampaikan oleh Faisal bahwa;

Pihak Korea Utara mengecam RUU tersebut dan memberikan peringatan bahwa Asia tidak akan membiarkan Negara bekas penjajah kembali muncul sebagai kekuatan militer dan sebagai aggressor. Pihak Korea Utara mengatakan Korea Utara dan Negara-negara Asia lainnya yang masih ingat dengan jelas tindak kriminal agresi yang dilakukan tentara kerajaan Jepang, dan tidak akan membiarkan setiap bentuk untuk kebangkitan kembali militerisme Jepang Korea Selatan yang beralirkan demokrat juga menunjukkan keprihatinannya. (Faisal Siagian, 19 Juni 1992) 


\section{Global Insight Journal}

Vol 02, No. 01

April-September 2017

ISSN 2541-318X

\section{KESIMPULAN}

Meskipun Jepang belum dapat merealisasikan sistim pertahanan yang mandiri pada era pasca Perang Dingin, upaya ke arah itu sudah pasti dan jelas. Hal ini dapat kita lihat dari wacana-wacana, statement hingga perdebatan yang intens di parlemen (Diet). Demikian pula ikhtiar setiap PM Jepang pasca Perang Dingin yang ingin agar negaranya mandiri dalam arti sebenarnya, yakni berdaulat dalam bidang politik, baik itu politik dalam negeri, maupun politik pertahanan keamanan, di samping apa yang sudah dicapai yakni berdikari (bahkan sudah raksasa) dalam bidang ekonomi.

Ikhtiar yang paling radikal, yang oleh banyak kalangan disebut manifestasi asli Jepang yang telah dikemukakan oleh PM Yoshiro Mori beberapa pekan setelah ia diangkat menjadi PM. Mori menyebut Jepang sebagai satu bangsa dewa dengan kaisar dipusatnya)(Tajuk Kompas, 7 April 2001). Apakah karena terlalu bersemangat, terlalu radikal, atau belum waktunya, Mori banyak mendapat kecaman. Namun apa dalihnya, Nasionalisme Jepang sudah bangkit kembali, sekalipun dalam format yang baru 


\section{Global Insight Journal}

Vol 02, No. 01

April-September 2017

ISSN 2541-318X

\section{DAFTAR PUSTAKA}

- Akhihito, 2003, Japan Defense, Urban Connection, Tokyo,Japan.

- Azra F. Vogel, 1990, Jepang No 1, Sinar Harapan, Jakarta.

- Bantarto Bandoro, 2000, Arsitektur Keamanan di Asia Pasifik, CSIS, Jakarta.

- Budi Winarno, 1995. Teori Hubungan Internasional, FISIPOL UGM, Yogyakarta.

- Ichiri ozawa, 2000, Blue Print Jepang Masa Kini, Tiara Wacana, Yogyakarta.

- Takafusa Nakamura, Perkembangan Ekonomi Jepang, UI Press, Jakarta.

- Yoshihiro Kunio, 1995, Kapitalisme semu Asia Tenggara, LP3ES, Jakarta. 